\title{
Reoperációs algoritmus és célvezérelt haemostasisterápia együttes, sikeres alkalmazása súlyos szívsebészeti vérzés kezelésében
}

\author{
Gombocz Károly dr. - Beledi Ágnes dr. - Botos Ferenc dr. \\ Wrana Győző dr. - Feiler Erzsébet dr. - Csécs Roland dr. \\ Rácz Zsombor dr. - Rashed Aref dr.
}

Zala Megyei Szent Rafael Kórház, Szívsebészeti Osztály, Zalaegerszeg

\begin{abstract}
Bevezetés: A szívmútéteket követő súlyos vérzés és transzfúzió jelentősen növeli a szövődményrátát és a mortalitást. A vérző beteg hatékony kezelésének feltétele a 'sebészi' és a coagulopathiás vérzés korai diagnosztikája. Rotációs thromboelastometria alkalmazása segíthet a reoperáció indikációjának felállításában, és célvezérelt haemostasisterápiával csökkentheti a vérveszteséget, a transzfúziót és a költségeket.

Célkitüzés: Korábbi betegeink vérzéses adataiból származtatott intézeti vérzéses-reoperációs protokoll kidolgozását és a módszer hatékonyságának vizsgálatát tüztük ki célul.

Módszer: Az osztályunkon korábban operált 1011 beteg (kontrollcsoport) adataiból a coagulopathiás és a 'sebészi' vérzés megkülönböztetésére statisztikai algoritmust hoztunk létre. Vérzéses-reoperációs protokollunkban az algoritmust viszkoelasztikus koagulációs teszttel és rizikóbesorolással együttesen alkalmaztuk. Egymást követő 112 operált betegünknél megvizsgáltuk a reoperációk gyakoriságát, indikációit, valamint a protokollnak a transzfúziókra és a direkt költségekre kifejtett hatását, korábbi gyakorlatunkkal összehasonlítva.

Eredmények: A vérzés miatt végzett reoperáció gyakorisága nem különbözött a vizsgált és a kontrollcsoport között $(6,2 \%$ vs. $5,4 \% ; \mathrm{p}=0,584)$. A reoperált betegeknél a vérzés-protokollcsoportban coagulopathiás vérzés önmagában nem, míg a kontrollcsoportban 12,7\%-ban fordult elő. A vérzéses-reoperációs protokoll alkalmazása mellett csökkent a vérzés $(\mathrm{p}=0,026)$, több betegnél alkalmaztunk fibrinogént $(\mathrm{p}<0,001)$, protrombinkomplex-koncentrátumot $(\mathrm{p}<0,001)$, tranexámsavat $(\mathrm{p}<0,001)$; a vörösvérsejt-transzfúziók száma $30 \%$-kal csökkent $(1,7 \pm 2,6 \mathrm{E}$ vs. $2,3 \pm$ $3,3 \mathrm{E} ; \mathrm{p}=0,012)$; a friss fagyasztott plazma vagy thrombocytatranszfúziók esetén a különbség nem volt szignifikáns. A módszer alkalmazásával betegenként -20 333 Ft, aktivitásalapú költséggel számolva -38200 Ft költségmegtakarítást értünk el.

Következtetés: Vérzéses-reoperációs protokollunk alkalmazásával csak 'sebészi' vérzés miatt végeztünk reoperációt, több esetben alkalmaztunk faktorkészítményt, antifibrinolitikumot, csökkent a vérveszteség, a vörvösvérsejt-transzfúziók száma, és költségmegtakarítást értünk el.

Orv Hetil. 2020; 161(34): 1414-1422.
\end{abstract}

Kulcsszavak: szívsebészet, perioperatív vérzés, POC-diagnosztika, reoperáció, transzfúzió, költséghatékonyság

\section{Successful combined application of reoperation protocol with target-guided hemostatic therapy for the treatment of severe bleeding in cardiac surgical patients}

Introduction: Bleeding and transfusions following cardiac surgery significantly increase the rate of complications. Early diagnosis of "surgical" and "coagulopathic" bleeding is a prerequisite for effective treatment. Thromboelastometry with targeted hemostasis therapy can help in setting up the indication for reoperation and reduction of blood loss, transfusions and costs.

Aim: We aimed to develop a local "reoperation for bleeding" protocol derived from the data of our former patients. Method: Based on data from 1011 cardiac surgical patients (control group), we developed a statistical algorithm to distinguish between "coagulopathic" and "surgical" bleeding. We used viscoelastic coagulation test and risk stratifica- 
tion. In 112 consecutive patients (study group), we examined the reoperations, and the impact of the protocol on the rates of transfusions and treatment costs.

Results: There was no difference in the rate of reoperations between the two groups $(6.2 \% \mathrm{vs.} 5.4 \% ; \mathrm{p}=0.584)$. No coagulopathic bleeding occurred in the study group, compared to $12.7 \%$ in the control group. In the study group, we experienced reduction in bleeding $(\mathrm{p}=0.026)$, an increased application of fibrinogen $(\mathrm{p}<0.001)$, prothrombin complex concentrate $(\mathrm{p}<0.001)$, and tranexamic acid $(\mathrm{p}<0.001)$. Red blood cell transfusions decreased by $30 \%$ $(1.7 \pm 2.6 \mathrm{E}$ vs. $2.3 \pm 3.3 \mathrm{E} ; \mathrm{p}=0.012)$. No difference was found in the amounts of fresh frozen plasma or platelet transfusions used. Calculated cost savings were HUF $-20,333$ per patient.

Conclusion: Using this algorithm, reoperations were performed only in cases of surgical bleeding. The amount of bleeding, requirement for transfusions and treatment costs were reduced.

Keywords: cardiac surgery, hemorrhage, point-of-care testing, reoperation, blood transfusion, cost effectiveness

Gombocz K, Beledi Á, Botos F, Wrana Gy, Feiler E, Csécs R, Rácz Zs, Rashed A. [Successful combined application of reoperation protocol with target-guided hemostatic therapy for the treatment of severe bleeding in cardiac surgical patients]. Orv Hetil. 2020; 161(34): 1414-1422.

(Beérkezett: 2020. április 2.; elfogadva: 2020. május 3.)

\section{Rövidítések}

ACT $=($ activated clotting time $)$ aktivált alvadási idő; BMI = (body mass index) testtömegindex; $\mathrm{CABG}=($ coronary artery bypass grafting) koszorúér-áthidalás; $\mathrm{CI}=$ (confidence interval) konfidenciaintervallum; DOAC $=$ (direct oral anticoagulant) direkt oralis antikoaguláns; ECC $=($ extracorporeal circulation) extracorporalis keringés; ECCT $=$ (extracorporeal circulation time) az extracorporalis keringés ideje; EuroSCORE $=($ European System for Cardiac Operative Risk Evaluation $) \mathrm{a}$ szívsebészetben használt kockázatbecslő modell; FFP = friss fagyasztott plazma; $\mathrm{Hgb}=$ hemoglobin; $\mathrm{GLM}=$ (general linear model) általános lineáris modell; INR = (international normalized ratio) nemzetközi normalizált ráta; $\mathrm{LMWH}=($ low-molecular-weight heparin) kis molekulatömegú heparin; $\mathrm{OAC}=$ oralis antikoaguláns; $\mathrm{OR}=$ (odds ratio) esélyhányados; $\mathrm{PCC}=$ (prothrombin complex concentrate) protrombinkomplex-koncentrátum; POC $=$ (point-of-care $)$ betegágy melletti; rFVIIa = aktivált rekombináns VII-es faktor; ROTEM = rotációs thromboelastometria; $\mathrm{RR}=($ risk rativ) relatív kockázat; $\mathrm{SD}=$ standard deviáció; TCT $=$ thrombocyta; TEE = transoesophagealis echocardiographia; vvt $=$ vörösvértest XCT $=$ az aortalefogás ideje

A súlyos vérzés és transzfúzió a szívsebészeti betegeknél közel tízszeres mortalitási rizikóval jár [1]. A sebészi és a coagulopathiás vérzés sok esetben együttesen jelentkezik, de masszív sebészi vérzés mellett coagulopathia is gyakran kialakul. A súlyos vérzés vagy pericardialis tamponád miatt végzett reoperációk előfordulása egy nemrégen publikált tanulmány szerint $6 \%$, akut mútéteknél pedig 15\% volt [2]. A reoperációk kockázati tényezői az alacsony BMI, a magasabb EuroSCORE, az alacsonyabb preoperatív fibrinogénkoncentráció, a műtétet megelőző 5 napon belül a kettős thrombocytaaggregáció-gátlás, a hosszú extracorporalis keringési idő és a kombinált CABG- és billentyúimplantáció $[2,3]$. Egy közel három évtizedet magában foglaló metaanalízis alapján a vérzés miatt végzett reoperáció növeli a mortalitást (OR: 3,3$)$, gyakoribb a stroke $(\mathrm{OR}: 1,9)$, a veseelégtelenség (OR: $2,4)$, a tartós gépi lélegeztetés (OR: 3,6 ) és a mechanikus keringéstámogatás alkalmazása (OR: 2,0) $[2,4]$.

A coagulopathia diagnosztikájában a hagyományos laborvizsgálatok nem kellően pontosak és késedelemmel járnak, viszont az ágy melletti (point-of-care, POC) viszkoelasztikus koagulációs teszt, a rotációs thromboelastometria (ROTEM) alkalmazásával a haemostasis zavara már 15-20 perc alatt diagnosztizálható és célzottan kezelhető [5]. Súlyos coagulopathiás vérzésnél a ROTEMtesztekkel célvezérelt haemostasiskezelés a faktorkészítmények alkalmazásával csökkenti a vérveszteséget és a transzfúziót [6]. Annak ellenére, hogy számos vizsgálat igazolta a célvezérelt haemostasiskezelés költséghatékonyságát $[7,8]$, a viszkoelasztikus POC-tesztek és a faktorkészítmények széles körú alkalmazását a költségnövelő hatásaiktól való alaptalan félelem akadályozza. A 'sebészi' vérzésnél a korai reoperáció az egyetlen hatékony kezelés, amellyel a további prokoaguláns kezelés és a felesleges transzfúziók elkerülhetók. A viszkoelasztikus POC-tesztek a coagulopathia kizárásával a korai reoperáció indikációjában is segíthetnek, ha a haemostasiszavart nem a Von Willebrand-faktor hiánya, thrombocytaaggregáció-gátlás vagy $\mathrm{LMWH}$-, oralis antikoaguláns (OAC)-, illetve direkt oralis antikoaguláns (DOAC)-kezelés okozza. A reoperációk indikációjának felállításában a viszkoelasztikus POC-tesztek diagnosztikus értékét a korábbi szívsebészeti tanulmányokban nem vizsgálták.

A súlyos vérzés ellátására nemzetközi és a magyar ajánlások intézeti protokoll alkalmazását javasolják $[9,10]$. A jelen tanulmányunkban célkitúzésünk egy komplex vérzéses-reoperációs protokoll kidolgozása és a módszer hatékonyságának vizsgálata volt a reoperációk indikációira, a transzfúziós kezelésre és a direkt költségekre. 
A reoperáció indikációi a kontrollcsoportban

I. Vérzés $>150 \mathrm{ml} /$ óra

Labordiagnosztika: ACT, INR, TCT-szám, aPTI, TI, se. fibrinogén Kezelés: A véralvadás azonnali, több támadásponton történő, majd célzott korrekciója:

Protamin, Exacyl, fibrinogén, PCC, rFVIIa, FFP, TCT, vvt transzfúziója

Transzfúziós küszöb $(\mathrm{Hgb}) \mathrm{CPB}<60 \mathrm{~g} / 1$, később $<85 \mathrm{~g} / 1$

Terápia ellenére további vérzés: REOPERÁCIÓ

II. Vérzés mellett romló keringési paraméterek vagy növekvő vasoconstrictorigény: ECHO-vizsgálat

Pericardialis tamponád: REOPERÁCIÓ

ACT = aktivált alvadási idő; aPTI = aktivált parciális tromboplasztin idő; $\mathrm{CPB}=$ cardiopulmonalis bypass; $\mathrm{ECHO}=$ szívultrahang-vizsgálat; $\mathrm{FFP}=$ friss fagyasztott plazma; $\mathrm{Hgb}=$ hemoglobin; INR = nemzetközi normalizált ráta; $\mathrm{PCC}=$ protrombinkomplex-koncentrátum; $\mathrm{rFVIIa}=$ rekombináns aktivált VII-es faktor; $\mathrm{TCT}=$ thrombocyta; $\mathrm{TI}=$ trombinidő; vvt = vörösvértest

\section{Módszer}

A protokoll megtervezéséhez osztályunk 2015-ben és 2016-ban operált betegeinek adatait dolgoztuk fel. Ebben az időszakban a vérzés kezelésére már faktorkészítményeket alkalmaztunk, de viszkoelasztikus POC-diagnosztika még nem volt. A reoperáció indikációit az 1 . táblázatban tüntettük fel. Az intraoperatív lelet alapján definiáltuk a reoperáció indokoltságát 'sebészi' vérzés miatt, coagulopathia miatt vagy nem indikált kategóriák szerint. A 'sebészi' vérzés csoportjában a reoperáció során egyértelmú 'sebészi' vérzésforrás igazolódott. A coagulopathiás csoportban a sebész a reoperáció során csak diffúz vérzést talált. Az utólag nem indikált csoportban a reoperáció során sem vérzés, sem haematoma nem volt, a reoperációt téves ultrahang-diagnózis miatt végeztük. Az adatbázis tartalmazta a legfontosabb anamnesztikus adatokat, ezen belül a vérzést is befolyásoló thrombocytaaggregáció-gátlást, valamint az induló hemoglobin ( $\mathrm{Hgb}$ )-koncentrációt, a protrombint (INR, international normalized ratio), a thrombocytaszámot és az EuroSCORE-t. Az intraoperatív adatok közül szerepeltettük a mútét típusát, az extracorporalis keringés idejét (ECCT), az aortalefogás idejét (XCT), a mütét alatti legalacsonyabb hőmérsékletet, a legalacsonyabb Hgb-koncentrációt, az alkalmazott vörösvérsejt (vvt)-, thrombocyta (TCT)-, friss fagyasztott plazma (FFP-) transzfúziók számát, az alvadásra ható készítmények dózisát (tranexámsav, fibrinogén, protrombinkomplex-koncentrátum [PCC], aktivált rekombináns VII-es faktor [rFVIIa]), szövetragasztó, cell-saver felhasználását, kiszámítottuk a mútét alatti folyadékegyenleget és vérzést. A posztoperatív adatok közül az első 6 óra órás vérzésfrakcióit, az öszszes posztoperatív vérzést, a vér- és faktorkészítmények dózisát, továbbá a legfontosabb szövődményeket és a mortalitást vizsgáltuk.

A hagyományosan kezelt kontrollcsoportból ( $\mathrm{n}=$ 1011 ) kiválasztottuk a „vérző betegek” csoportját, akiknél az összes posztoperatív vérzés több mint $1200 \mathrm{ml}$ volt $(\mathrm{n}=201)$. Ennek a csoportnak a kumulatív vérzéses

\section{Szívsebészeti reoperációs protokoll}

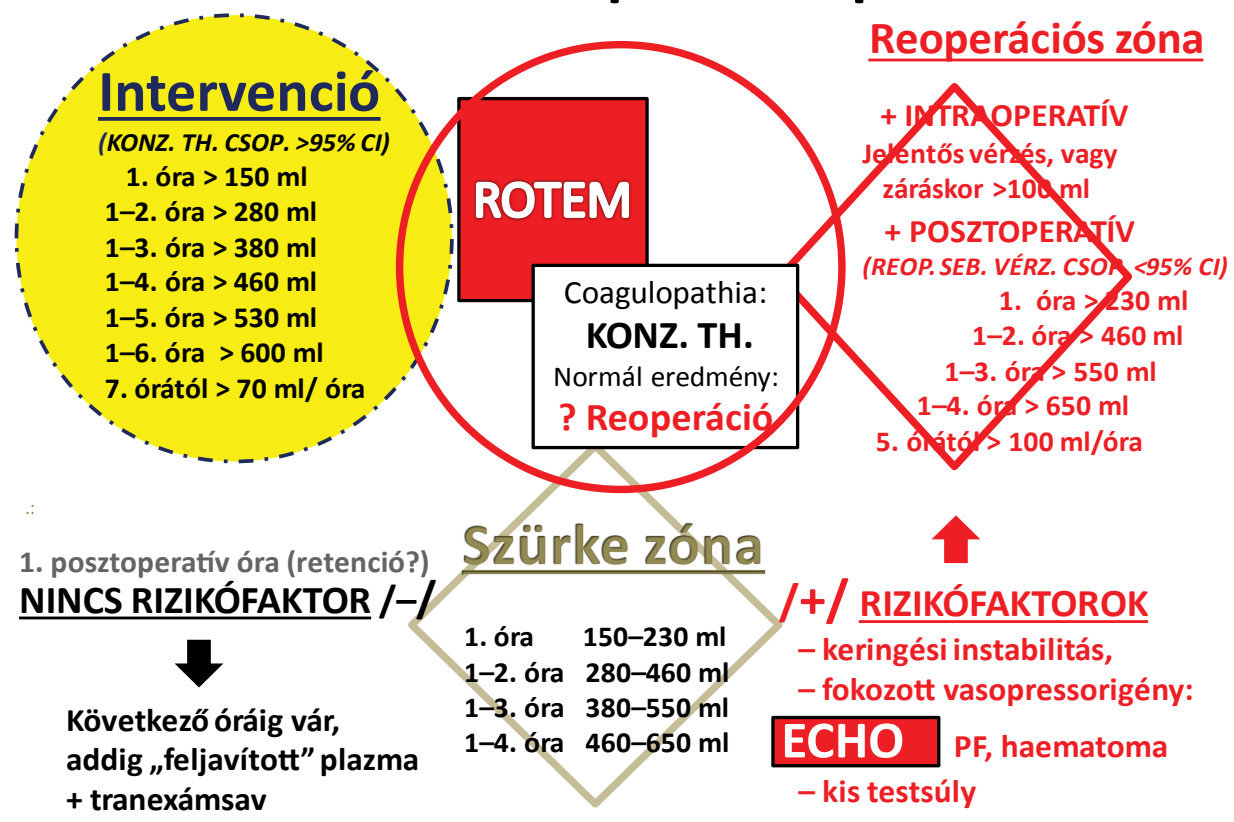

1. ábra

Vérzéses statisztikai algoritmuson alapuló reoperációs protokoll. A vérzésküszöb feletti vérzés esetén ROTEM-vizsgálatot végzünk. Amennyiben coagulopathia nem igazolódik, a vérveszteségtől és a kockázati tényezőktől függően a beteget reoperáljuk, vagy egy órát várakozunk, és feljavítottplazma-kezelést alkalmazunk a következő órás vérzésfrakció alapján történő újraosztályozással

$\mathrm{ECHO}=$ szívultrahang-vizsgálat; $\mathrm{PF}=$ pericardialis folyadékgyülem; ROTEM = rotációs thromboelastometria 
adatai alapján állítottuk össze az intervenciós algoritmust. A vérzés határértékeinek meghatározásához a vérző, nem reoperált csoport kumulatív órás vérzésfrakciói 95\%-os konfidenciaintervallumának (CI) felső határértékét vettük figyelembe (intervenciós zóna). A reoperált betegek közül kiválasztottuk azokat, akiknél biztosan 'sebészi' vérzésforrás volt, és a vérzés szempontjából jellemző csoporttulajdonság meghatározásához a kumulatív órás vérzésfrakciók 95\%-os CI-nak alsó határértékét vettük figyelembe (reoperációs zóna). A protokoll alkalmazásával, amennyiben a kumulatív vérzés egy adott órában meghaladta az intervenciós zóna határértékét, viszkoelasztikus POC-tesztet végeztünk. Coagulopathia esetén célzott kezelést alkalmaztunk, és amennyiben a haemostasiskorrekció után a vérzés meghaladta az intervenciós küszöböt, újraosztályoztuk a beteget. Amennyiben koagulációs zavar viszkoelasztikus POC-teszttel nem igazolódott, és a vérzésfrakciók elérték a reoperációs zóna határértékét, vagy a vérzés ennél kevesebb volt (szürke zóna), de a beteg a magas rizikójú csoportba tartozott, akkor reoperáció mellett döntöttünk. A vérzéses statisztikai algoritmuson alapuló reoperációs protokollunkat az 1 . ábrán tüntettük fel.

Viszkoelasztikus koagulációs vizsgálatra ROTEM delta készüléket (Instrumentation Laboratory, Werfen Company, Bedford, MA, USA) alkalmaztunk. A POCteszt diagnosztikus és terápiás algoritmusát a 2. ábrán foglaltuk össze. Az új protokoll alkalmazásával 2 hónap

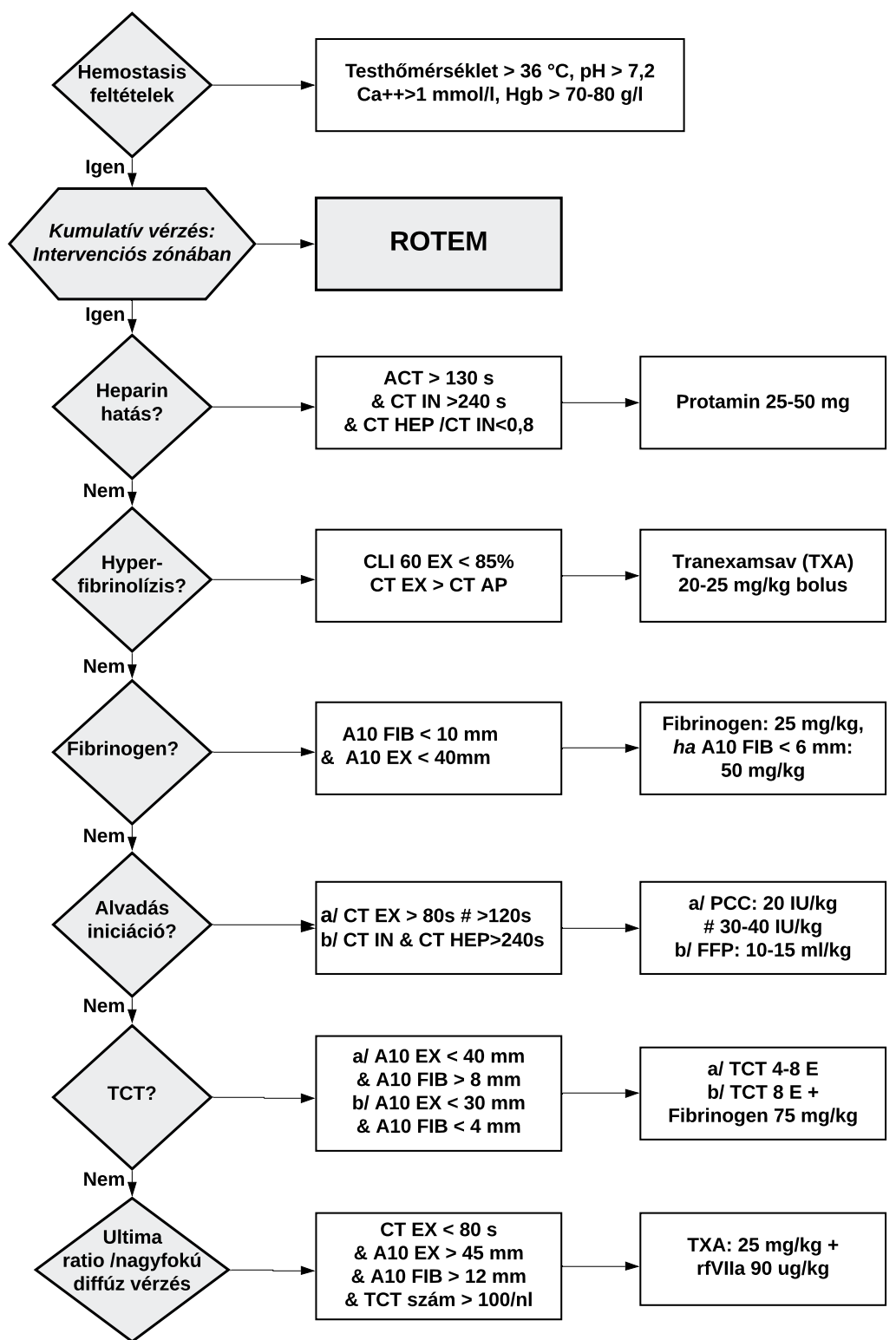

2. ábra $\quad$ POC-teszt vezérelte haemostasiskezelés algoritmusa a vérzés-protokollcsoportban. ROTEM-tesztek: EXTEM (EX), INTEM (IN), FIBTEM (FIB), APTEM (AP), HEPTEM (HEP). ROTEM mérési eredmények: Clot Lysis Index 60 percnél (CLI 60), alvadási idő (CT), alvadékszilárdság amplitúdója 10 percnél (Al0)

ACT = aktivált alvadási idő; CLI = Clot Lysis Index; CT = alvadási idő; FFP = friss fagyasztott plazma; PCC = protrombinkomplex-koncentrátum; rfVIIa = rekombináns aktivált VII-es faktor; ROTEM = rotációs thromboelastometria; TCT $=$ thrombocyta; TXA = tranexámsav 
tanulási fázis után 3 hónapos vizsgálatot végeztünk, amelybe bevontuk az adott időszakban operált összes beteget (vérzés-protokollcsoport, $\mathrm{n}=112$ ). A kontroll vizsgálati csoporthoz képest a sebészi technikai és az aneszteziológiai módszerek, ezen belül az extracorporalis keringési technika és az antikoaguláns kezelés (ECC előtt Na-heparin $300 \mathrm{E} / \mathrm{kg}$, cél ACT>400 s, protamin/ heparin arány: 1:1) nem változott. A transzfúzió indikációi a két vizsgálati időszakban nem különböztek (transzfúziós küszöb ECC alatt $60 \mathrm{~g} / 1$, ezen kívül $85 \mathrm{~g} / \mathrm{l}$ ).

A költségelemzésnél a direkt vérzéskezeléssel, a labordiagnosztikával, valamint a reoperációval kapcsolatos változókat vizsgáltuk (vvt-, FFP-, TCT-transzfúziók, faktorkészítmények, hagyományos és ROTEM-diagnosztika, humán albumin, szövetragasztók, cell-saver, reoperációk). Az aktuális költségeknél a Kórházi Gyógyszertár, a Vérellátó és a kórház Beszerzési Osztályának 2018-as bruttó árait vettük figyelembe. A költségek összehasonlításakor az egy betegre jutó költségeket kalkuláltuk.

\section{2. táblázat |Alap-, anamnesztikus és mútéti adatok}

\begin{tabular}{|c|c|c|c|}
\hline & $\begin{array}{l}\text { Vérzés- } \\
\text { protokollcsoport } \\
(\% \text {; átlag } \pm \text { SD })\end{array}$ & $\begin{array}{l}\text { Kontrollcsoport } \\
\text { (\%; átlag } \pm \text { SD) }\end{array}$ & $\mathrm{p}$ \\
\hline Nem (férfi) & 70,3 & 65,0 & 0,266 \\
\hline Kor & $66,8 \pm 9,5$ & $64,9 \pm 9,9$ & 0,056 \\
\hline $\mathrm{BMI}<25 \mathrm{~kg} / \mathrm{m}^{2}$ & 24,3 & 18,3 & 0,124 \\
\hline Bal kamrai EF & $57,8 \pm 10,6$ & $57,2 \pm 10,3$ & 0,599 \\
\hline GFR & $69,0 \pm 18,1$ & $70,9 \pm 18,4$ & 0,307 \\
\hline Hypertonia & 83,8 & 81,6 & 0,572 \\
\hline Diabetes mellitus & 45,0 & 30,2 & 0,004 \\
\hline COPD & 16,2 & 11,7 & 0,164 \\
\hline EuroSCORE II. & $3,4 \pm 5,0$ & $2,7 \pm 4,2$ & 0,086 \\
\hline Kombinált CABG-mútét & 11,7 & 10,4 & 0,668 \\
\hline Aortamútét & 6,3 & 4,9 & 0,504 \\
\hline Aortadissectio & 3,6 & 2,1 & 0,301 \\
\hline Infektív endocarditis & 2,3 & 1,8 & 0,749 \\
\hline Klopidogrél & 25,2 & 16,4 & 0,019 \\
\hline Aszpirin & 40,5 & 34,1 & 0,578 \\
\hline Kettős TAG & 18,0 & 12,1 & 0,073 \\
\hline Reoperáció (redo) & 2,7 & 2,7 & 0,984 \\
\hline Akut mútét & 4,5 & 6,1 & 0,491 \\
\hline Cc. Hgb (preoperatív) & $135 \pm 16,7$ & $137 \pm 16,1$ & 0,174 \\
\hline Cc. TCT (preoperatív) & $212 \pm 68$ & $223 \pm 64$ & 0,086 \\
\hline ECCT & $111 \pm 50$ & $114 \pm 56$ & 0,682 \\
\hline XCT & $80 \pm 33$ & $78 \pm 37$ & 0,726 \\
\hline
\end{tabular}

$\mathrm{BMI}=$ testtömegindex $; \mathrm{CABG}=$ koszorúér-áthidalás; $\mathrm{cc} . \mathrm{Hgb}=$ hemoglobinkoncentráció; $\quad \mathrm{cc}$. TCT = thrombocytakoncentráció; COPD = krónikus obstruktív tüdőbetegség; ECCT $=$ az extracorporalis keringés ideje; $\mathrm{EF}=$ ejekciós frakció; $\mathrm{GFR}=$ glomerulusfiltrációs ráta; $\mathrm{SD}=$ standard deviáció; $\mathrm{TAG}=$ thrombocytaaggregáció-gátló; $\mathrm{XCT}=\mathrm{az}$ aortalefogás ideje
A statisztikai eredményeket átlag \pm SD, /medián és \% formájában adtuk meg. Folytonos változóknál a normáleloszlást Kolmogorov-Szmirnov-teszttel, a csoportok közötti varianciák homogenitását Levene-teszttel vizsgáltuk. A csoportok összehasonlításakor a folytonos változók esetében t-tesztet, illetve nonparametrikus (Mann-Whitney-féle U-) tesztet, GLM Multivariate Analysis-t, a nem folytonos változóknál pedig $\chi^{2}$-próbát alkalmaztunk. A különbséget szignifikánsnak tekintettük $\mathrm{p}<0,05$ esetében. A statisztikai elemzéshez IBM SPSS Statistics Version 20 (IBM Corp., Armonk, NY, USA) programcsomagot alkalmaztunk.

\section{Eredmények}

A két vizsgálati csoport alap-, anamnesztikus és mútéti adatait a 2. táblázatban foglaltuk össze. Szignifikáns különbséget a diabetes mellitus és a mútétig szedett klopidogrél kezelés esetében találtunk, a gyakoriság mindegyik esetben a vérzés-protokollcsoportban volt magasabb.

A kontrollcsoportban 55 esetben végeztünk reoperációt $(5,4 \%)$. A reoperált betegek $87,3 \%$-ában 'sebészi' vérzésforrást, 7,3\%-ában coagulopathiát találtunk, míg utólag nem indikált reoperáció - amikor a mútétet hemodinamikailag instabil betegnél szívtamponád gyanúja miatt végeztük, és sem vérzés, sem haematoma nem volt - 5,5\%-ban fordult elö (3. ábra).

A vérzés-protokollcsoport betegeinél vérzés miatti intervencióra és ezen belül ROTEM-vizsgálatra 18\%-ban került sor (4. ábra). A vérzéses algoritmus alapján az 'intervenciós' csoportba sorolt betegek közül a 'reoperációs' zónában 44\%-ban, míg a 'szürke' zónában 18\%-ban történt reoperáció. Vérzés miatti reoperációt összesen a betegek 6,2\%-ánál végeztünk, ami statisztikailag nem

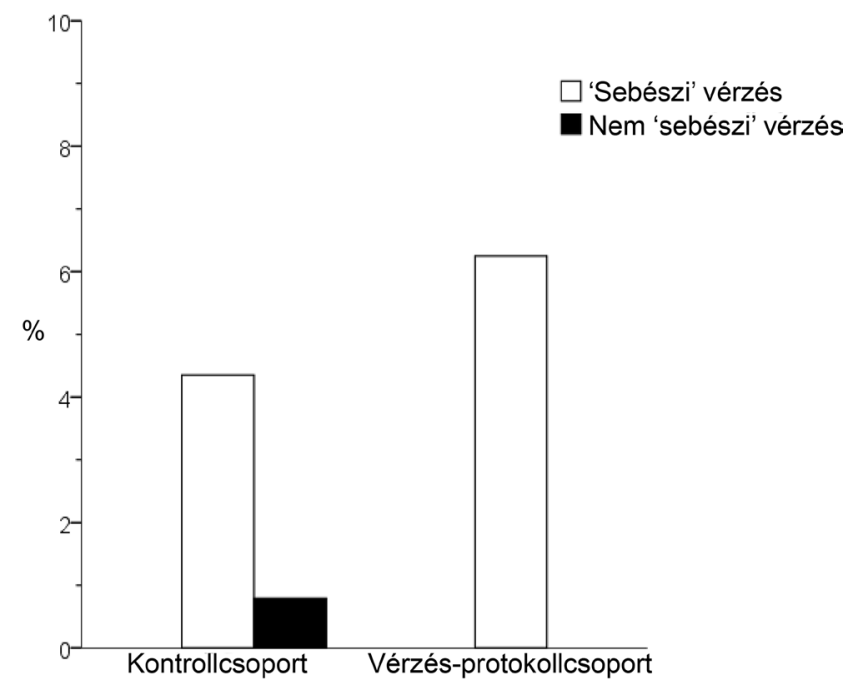

3. ábra $\mid$ A reoperációk indokoltsága a mútéti lelet alapján a két csoportban. A vérzés-protokollcsoportban csak 'sebészi' vérzést talált a sebész. A kontrollcsoportban a reoperációra kerülő betegek 12,8\%-ánál sebészi vérzésforrás nem igazolódott 


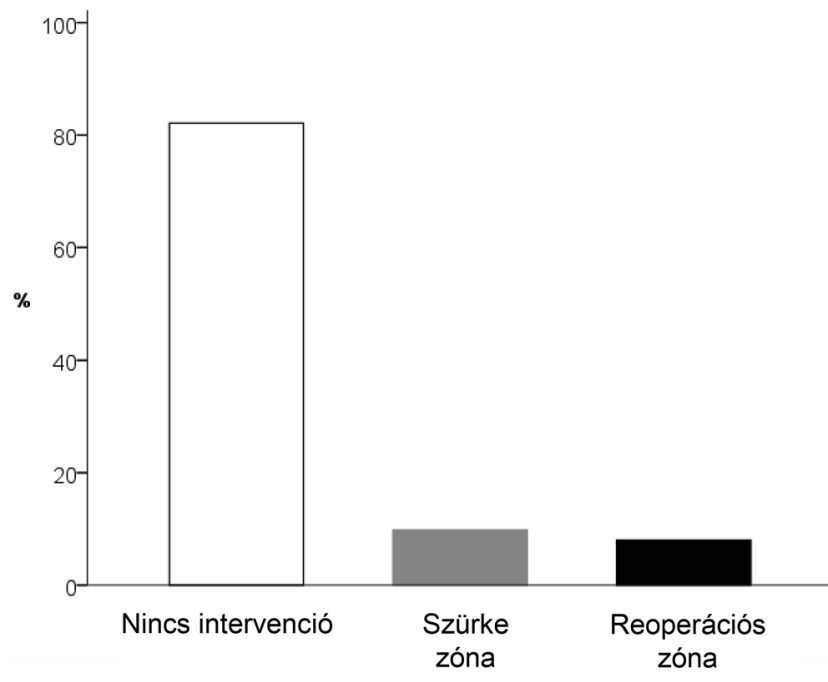

4. ábra a vérzés-protokollcsoportban. A kumulatív vérzés alapján szürke zónába a betegek $9,9 \%$-a, míg a reoperációs zónába $8,1 \%$-a került

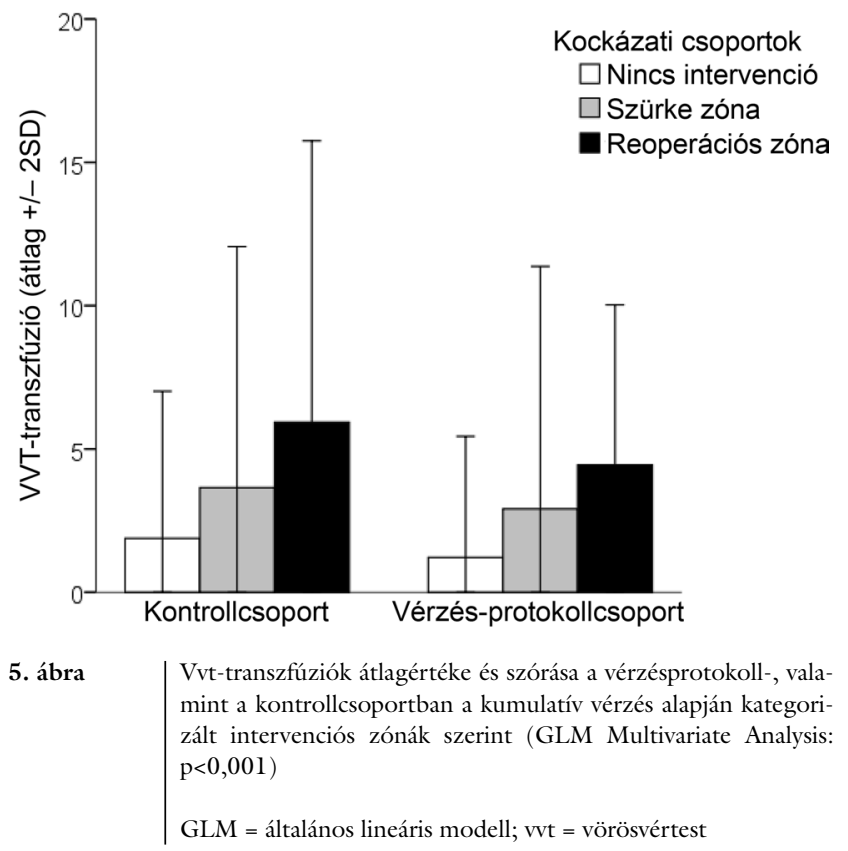

különbözött a kontrollcsoport reoperációs gyakoriságától $(\mathrm{p}=0,584)$, viszont protokollunk alkalmazásával csak 'sebészi' vérzés miatt történt reoperáció.

A vizsgált csoportban a posztoperatív vérzés mennyisége a kontrollcsoporthoz viszonyítva kevesebb volt (medián: 675 vs. $770 \mathrm{ml}, \mathrm{p}=0,026$ ). Az egy betegre jutó vvt-transzfúziók száma 30\%-kal csökkent a vérzésprotokollcsoportban, a kontrollcsoporttal összehasonlítva $(1,6 \pm 2,6 \mathrm{E}$ vs. $2,3 \pm 3,3 \mathrm{E} ; \mathrm{p}=0,012)$. A transzfúziók számának összehasonlíthatósága érdekében a kontrollcsoport betegeit is utólag kategorizáltuk, a vérzéses algoritmusnak megfelelően. A vérzéses algoritmus kategóriái szerinti eloszlást a 5. ábrán tüntettük fel.

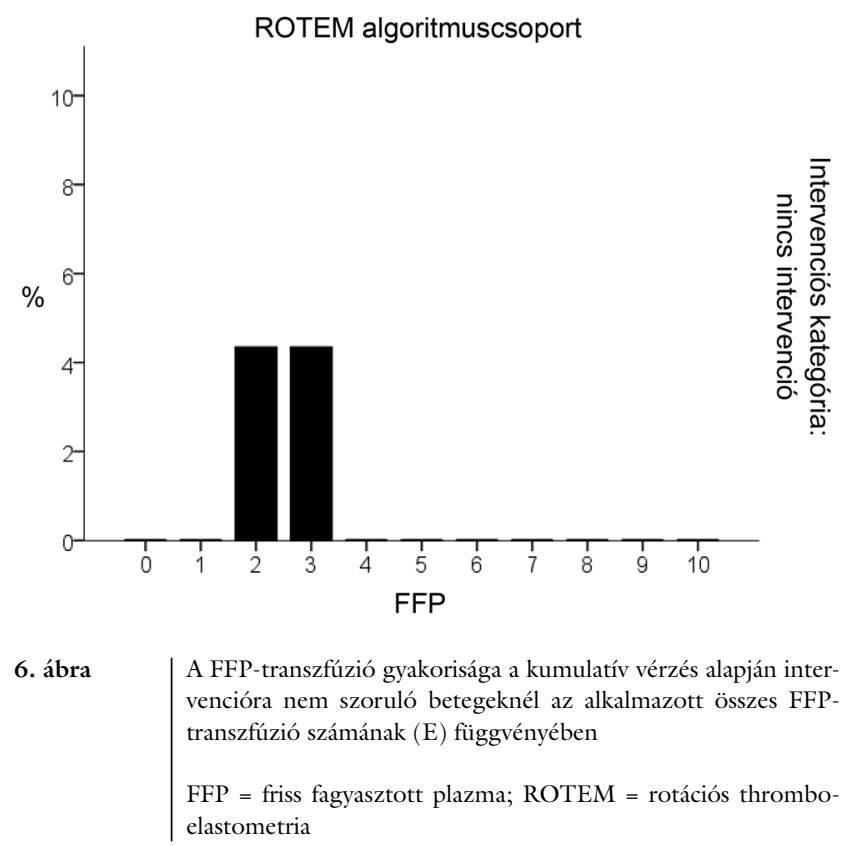

A FFP-transzfúzió 34\%-kal volt kevesebb a vérzés-protokollcsoportban, de a különbség nem volt szignifikáns $(0,62 \pm 1,7 \mathrm{E}$ vs. $0,93 \pm 2,3 \mathrm{E} ; \mathrm{p}=0,094)$. A TCT-felhasználás növekedett, de a különbség nem volt szignifikáns $(0,58 \pm 2,2 \mathrm{E}$ vs. $0,28 \pm 1,4 \mathrm{E} ; \mathrm{p}=0,177)$. A vérzéses kockázati csoportok alcsoportelemzésénél FFP „luxus" transzfúziót találtunk az intervenciót nem igénylő csoportban, ami az összes beteg közel 10\%-át érintette (6. ábra). A vérzés kezeléséhez a viszkoelasztikus POC-diagnosztika mellett, a kontrollcsoporttal öszszehasonlítva, több beteg kapott tranexámsavat $(54,1 \%$ vs. $8,0 \% ; \mathrm{p}<0,001)$, fibrinogént $(8,0 \%$ vs. $1,4 \% ; \mathrm{p}<0,001)$ és 4 komponensü PCC-t $(6,3 \%$ vs. $0,9 \% ; \mathrm{p}<0,001)$.

A vérzés-protokollcsoport és a kontrollcsoport vérzéssel összefüggő direkt költségeinek öszehasonlítása alapján betegenként 20333 Ft-os költségmegtakarítását értünk el. A vérkészítmények aktivitásalapú költségének kalkulációjával számolva az 1 betegre jutó megtakarítás $38200 \mathrm{Ft}$ volt (3. táblázat) [11].

\section{Megbeszélés}

Vizsgálatunkban, a 'sebészi' és a coagulopathiás vérzés kezelésére intézeti vérzéses-reoperációs protokollt dolgoztunk ki, amely a korábbi betegeink adataiból származtatott vérzéses algoritmust, a viszkoelasztikus méréseken alapuló célvezérelt haemostasiskezelést, valamint szívultrahang-vizsgálatot is magában foglaló rizikóbesorolást tartalmaz. A protokoll alkalmazásával a reoperációt igénylő betegeknél minden esetben 'sebészi' vérzésforrás igazolódott, csökkenteni tudtuk a posztoperatív vérveszteséget, a vvt-transzfúziók számát, és költségmegtakarítást értünk el.

Súlyos vérzésnél a vérveszteséget az etiológia gyors tisztázásával, majd a coagulopathiás, illetve 'sebészi' vér- 


\begin{tabular}{|c|c|c|c|c|}
\hline & Költség/E, db & $\begin{array}{l}\text { Kontroll/n = } 1010 \\
1 \mathrm{E} \mathrm{v.} \mathrm{db/beteg} \\
\text { Ft/beteg }\end{array}$ & $\begin{array}{l}\text { VPCS/n = } 112 \\
1 \mathrm{Ev} . \mathrm{db} / \text { beteg } \\
\text { Ft/beteg }\end{array}$ & Különbség \\
\hline $\operatorname{Vvt}(\mathrm{E}) \quad * \times 3,5$ & $8319 \mathrm{Ft} / \mathrm{E}$ & $2,3 / 19230 \mathrm{Ft}$ & $1,6 / 13667 \mathrm{Ft} \times * 3,5$ & $\begin{array}{l}-5563 \mathrm{Ft} \\
-19470 \mathrm{Ft}^{*}\end{array}$ \\
\hline $\begin{array}{l}\mathrm{FFP}(\mathrm{E}) \\
\quad * \times 3,5\end{array}$ & $11000 \mathrm{Ft} / \mathrm{E}$ & $0,93 / 10293 \mathrm{Ft}$ & $0,62 / 6875 \mathrm{Ft} \times * 3,5$ & $\begin{array}{l}-3418 \mathrm{Ft} \\
-11963 \mathrm{Ft}^{*}\end{array}$ \\
\hline $\begin{array}{r}\operatorname{TCT}(\mathrm{E}) \\
* \times 3,5\end{array}$ & $6400 \mathrm{Ft} / \mathrm{E}$ & $0,28 / 1823 \mathrm{Ft}$ & $0,57 / 3657 \mathrm{Ft} \times * 3,5$ & $\begin{array}{l}1834 \mathrm{Ft} \\
6419 \mathrm{Ft}^{*}\end{array}$ \\
\hline Fibrinogén & $87097 \mathrm{Ft} / \mathrm{db}$ & $0,045 / 3967 \mathrm{Ft}$ & $0,134 / 11665 \mathrm{Ft}$ & $7698 \mathrm{Ft}$ \\
\hline 4C PCC & $30135 \mathrm{Ft} / \mathrm{db}$ & $0,020 / 597 \mathrm{Ft}$ & $0,080 / 2422 \mathrm{Ft}$ & $1825 \mathrm{Ft}$ \\
\hline rFVIIa & $879401 / d b$ & $0,0019 / 1741 \mathrm{Ft}$ & 0 & $-1741 \mathrm{Ft}$ \\
\hline $\begin{array}{l}\text { Humán albumin** } \\
20 \% 100 \mathrm{ml} \times 0,66 \text { (ECC prime) }\end{array}$ & $18497 \mathrm{Ft} / \mathrm{db}$ & $12208 \mathrm{Ft}$ & 0 & $-12208 \mathrm{Ft}$ \\
\hline Reoperáció (nem indikált) & $250000 \mathrm{Ft} /$ mútét & $0,008 / 1980 \mathrm{Ft}$ & 0 & $-1980 \mathrm{Ft}$ \\
\hline Szövetragasztó & $\begin{array}{l}\text { Teljes költség adott } \\
\text { időszakban }\end{array}$ & $\begin{array}{l}5242354 \mathrm{Ft} / 1010 \\
5190 \mathrm{Ft} / \text { fó }^{\prime \prime}\end{array}$ & $\begin{array}{l}438520 \mathrm{Ft} / 112 \\
3915 \mathrm{Ft} / \text { fö }^{\prime \prime}\end{array}$ & $-1275 \mathrm{Ft}$ \\
\hline Szövetragasztó-mátrix & $\begin{array}{l}\text { Teljes költség adott } \\
\text { időszakban }\end{array}$ & $\begin{array}{l}13580343 \mathrm{Ft} / 1010 \\
13446 \mathrm{Ft} / \text { fó }^{\prime \prime}\end{array}$ & $\begin{array}{l}880503 / 112 \\
7862 \mathrm{Ft} / \text { fó }^{\prime \prime}\end{array}$ & $-5584 \mathrm{Ft}$ \\
\hline Cell-saver & $68960 \mathrm{Ft} / \mathrm{set}$ & $0,0436 / 3007 \mathrm{Ft}$ & $0,0268 / 1848 \mathrm{Ft}$ & $-1159 \mathrm{Ft}$ \\
\hline Serafol kártya & $750 \mathrm{Ft}$ & $2,3 \times 750=1725 \mathrm{Ft}$ & $1,6 \times 750=1200 \mathrm{Ft}$ & $-525 \mathrm{Ft}$ \\
\hline $\begin{array}{l}\text { Laborköltségek } \\
\text { (aPTI, TI, INR, fibrinogén) }\end{array}$ & & $1837 \mathrm{Ft}$ & 0 & $-1837 \mathrm{Ft}$ \\
\hline $\begin{array}{l}\text { ROTEM-kitek } \\
4 \times 0,18\end{array}$ & $5000 \mathrm{Ft} / \mathrm{db}$ & 0 & $3600 \mathrm{Ft}$ & $3600 \mathrm{Ft}$ \\
\hline+ & & $-77044 \mathrm{Ft}$ & $56711 \mathrm{Ft}$ & \\
\hline Betegenkénti összes megtakarítás: & & & & $\begin{array}{l}-20333 \mathrm{Ft} \\
-38200 \mathrm{Ft}^{*}\end{array}$ \\
\hline
\end{tabular}

*Aktivitásalapú szorzó; **A humán albumin alkalmazásának indikációja az extracorporalis keringés következtében kialakuló thrombocytadisz funkció csökkentése volt [11].

aPTI = aktivált parciális tromboplasztinidő $\mathrm{E}=$ egység; ECC = extracorporalis keringés; FFP = friss fagyasztott plazma; INR = nemzetközi nor malizált ráta; $\mathrm{PCC}=$ protrombinkomplex-koncentrátum; rFVIIa = aktivált rekombináns VII-es faktor; ROTEM = rotációs thromboelastometria; TCT $=$ thrombocyta; $\mathrm{TI}=$ trombinidő; VPCS = vérzés-protokollcsoport; vvt = vörösvértest

zés célzott, korai kezelésével lehet csökkenteni. A mütét során kialakuló coagulopathia leggyakoribb oka a mútét napjáig fenntartott thrombocytaaggregáció-gátló kezelés, a hemodilúció, a hypothermia, a residualis heparinhatás vagy a szükségesnél nagyobb dózisban adott protamin, a lumenes vérzés mellett kialakuló faktorhiány, a hiperfibrinolízis és az extracorporalis keringés következtében károsodott thrombocyta (Ib-receptor)-funkció lehet [5]. Hipoperfúzió során az endotheldiszfunkció következtében trombomodulin-trombin komplex képződik, amely a protein $\mathrm{C} / \mathrm{S}$ aktiválásával Va- és VIIIafaktor-gátlást okoz; ez gátolja a további trombin képződését [12] ezenkívül csökken a thrombocytaaktiváció, és fokozódik a fibrinolízis is. A cell-saver nagy volumenú alkalmazásával alvadásifaktor-hiány és thrombocytopenia keletkezik. A viszkoelasztikus POC-tesztekkel nyomon követhető az alvadás folyamatának teljes spektruma, kimutatható az iniciációs, amplifikációs, fibrinpolimerizációs és alvadékstabilizációs fázis vagy a fibrinolízis zavara, ami célzott kezelést, ezen belül elsősorban faktorpótlást tesz lehetővé. A viszkoelasztikus koagulációs POC-tesztek azonban nem alkalmasak a thrombocytafunkció vizsgálatára, a Von Willebrand-faktor hiányának kimutatására vagy a gyógyszeres thrombocytaaggregáció-gátlók, a LMWH (low-molecular-weight heparin), az oralis antikoagulánsok hatásának pontos mérésére. Ez alól kivételt képez a DOAC-ok esetén az újgenerációs viszkoelasztikus POC-készülék, a ClotPro. Szívsebészeti vérzések kezelésében a célvezérelt haemostasiskezelés egy nemrégen publikált metaanalízis eredménye szerint hatékonyan csökkentette a posztoperatív vérzést és transzfúziót [13]. $\mathrm{Az}$ aggregometria alkalmazása a thrombocytafunkció vizsgálatával tovább javíthatja a diagnózis pontosságát szívsebészeti betegeknél [14]. Súlyos 'sebészi' vérzés ritkábban fordult elő, amikor sebészi ellenőrző lista (checklist) szerint ellenőrizték a potenciális vérzési helyeket, és a reoperációk gyakorisága is közel $40 \%$-kal csökkent [15]. 
A mütét után jelentkező 'sebészi' vérzésnél a vérveszteség csak a korai reoperációval csökkenthető. Minden késlekedés - akár a diagnosztikában, akár további próbálkozás a konzervatív terápiával - a vérveszteséget fokozza, a szívtamponád kialakulásának kockázatát növeli, és magasabb mortalitással jár [16]. A reoperáció során, korábbi vizsgálatok szerint, az esetek harmadában nem találtak 'sebészi' vérzésforrást, viszont ebben a csoportban a mortalitás magasabb volt [4]. Egy korábbi tanulmány szerint viszkoelasztikus POC-teszt alkalmazásával a reoperációk száma csökkenthető volt [17]. Vizsgálatunkban a reoperációk gyakorisága nem csökkent, viszont 'nem sebészi' vérzés a reoperált betegek között nem volt. Echocardiographiás vizsgálattal, akár TEE-vel is diagnosztikus dilemmát okozhat a pericardialis zsír jelenléte, amely haematoma képét utánozhatja. Az instabil keringésû beteg így a téves diagnózis miatt reoperációra is kerülhet, ami tovább növelheti a kockázatot. A korábbi, utólag nem indikált eseteket vizsgálva a téves tamponád diagnózisa mellett nem volt jelentősebb vérzés, így az új protokoll alkalmazásával ilyen esetekben a reoperáció elkerülhetôvé válhat.

A két vizsgált csoport alapadatait összehasonlítva a vérzés-protokollcsoport vérzés szempontjából nagyobb kockázatú volt, mivel gyakoribb volt a diabetes mellitus előfordulása, és a betegek közül többen nem hagyták el a klopidogrélt a műtét előtt. A magasabb vérzési rizikó ellenére a vérzés-protokollcsoportban a posztoperatív vérzés és a vvt-transzfúziók száma szignifikánsan kevesebb volt, a vvt-felhasználás 30\%-kal, a FFP pedig 34\%kal csökkent a kontrollcsoporttal összehasonlítva. A mútéti számban osztályunkhoz hasonló Brandenburgi Szívcentrumban a viszkoelasztikus koagulációs POCtesztek bevezetése után a vvt-felhasználás 25\%-kal csökkent, míg a FFP-felhasználás nem változott. Itt koagulációs POC-tesztet a betegek 95\%-ánál alkalmaztak [8]. Számos korábbi tanulmány igazolta, hogy a viszkoelasztikus POC-tesztek alapján végzett, terápiás algoritmushoz kapcsolt korai, célorientált haemostasiskezelés csökkentette a vvt-, a FFP- és a TCT-transzfúziók számát [18-24]. A legújabb, a szívsebészetben célvezérelt haemostasiskezeléssel foglalkozó metaanalízisben a transzfúziók számában szignifikáns csökkenést mutattak ki (vvt: RR: 0,89; FFP: RR: 0,59; TCT: RR: 0,81) [13]. Alcsoportelemzés során a 'nem vérző' csoportban jelentős számú indikáció nélkül alkalmazott FFP-transzfúziót találtunk. A FFP „luxus” transzfúziók gyakoriságát egy korábbi angliai tanulmányban 43\%-ra becsülték [25]. Az indikáció nélküli FFP-transzfúzió egyik oka a vérzés szempontjából magas kockázatú betegek korábbi gyakorlat szerinti prevenciós kezelése volt. A prevencióban alkalmazott FFP a jelenlegi guideline-ok alapján kontraindikált $[9,10]$.

Költségelemzésünkben csak a direkt vérzéses költségeket kalkuláltuk, és így is jelentős megtakarítást értünk el. A Cost of Blood Consensus Conference kezdeményezé- sére az USA és Európa két-két kórházában a vérkészítmények valós költségét határozták meg [26]. A számításhoz aktivitásalapú elszámolással minden lehetséges járulékos költséget figyelembe vettek. A kalkulált költségszorzó az 1:3,2-1:4,8 közötti tartományban volt. A különbség az egyes országok eltérő gazdasági fejlettségéből, illetve az eltérő bérköltségekből adódott. A költségszorzó Magyarországra vetített értékét egy korábbi közleményben 1:3,5-re becsülték [7], amit vizsgálatunkban is alkalmaztunk. A Brandenburgi Szívcentrumban a célvezérelt haemostasiskezeléssel 44\%-os költségcsökkenést értek el, és a ROTEM havi fenntartási költsége a megtakarításnak csak kevesebb mint 5\%-át tette ki [18].

Vizsgálatunk korlátja a vérzés-protokollcsoport viszonylagosan alacsony esetszáma volt, ezért valószínúsíthető, hogy a reoperációs protokoll specificitását túlbecsültük. A vérzés-protokollcsoport vérzési kockázata magasabb volt, mivel több volt a diabeteses beteg, több beteg kapott mütét előtt klopidogrélt és kombinált thrombocytaaggregáció-gátló kezelést, ezért alulbecsülhettük a protokoll kedvező hatását a vérzésben, a vérkészítmény-felhasználásban és a költségek csökkentésében. Későbbi, nagyobb esetszámú, prospektív tanulmány adhat pontosabb becslést a módszer diagnosztikus értékérôl és a FFP-, valamint TCT-transzfúziókra kifejtett hatásairól.

Anyagi támogatás: A vizsgálathoz a ROTEM-reagenseket a CSL Behring Kft. biztosította, a vizsgálat megírása és a kapcsolódó kutatómunka egyéb anyagi támogatásban nem részesült.

Szerzôi munkamegosztás: G. K.: Részt vett az irodalomkutatásban, az adatgyújtésben, kidolgozta a statisztikai algoritmusokat, részt vett a vérzéses-reoperációs protokoll kidolgozásában, megtervezte a vizsgálatot, részt vett a vizsgálat kivitelezésében, a statisztikai feldolgozást végezte, megírta a cikk alapverzióját. B. Á.: Részt vett az irodalomkutatásban, az adatgyưjtésben, a vérzéses-reoperációs protokoll kidolgozásában, a vizsgálat kivitelezésében, átolvasta és javította a cikket. B. F., W. Gy., F. E., Cs. R., R. Zs.: Részt vett az adatgyüjtésben, a vizsgálat kivitelezésében, átolvasta és javította a cikket. R. A.: Részt vett a vérzéses-reoperációs protokoll kidolgozásában, az irodalomkutatásban, átolvasta és javította a cikket. A cikk végleges változatát valamennyi szerző elolvasta és jóváhagyta.

Érdekeltségek: A szerzőknek nincsenek érdekeltségeik.

\section{Köszönetnyilvánítás}

Köszönetet mondunk a Planmed Kft.-nek és a CSL Behring Kft.-nek, hogy biztosították a vizsgálathoz szükséges ROTEM delta készüléket, illetve a ROTEM-reagenseket, valamint Jankó Rebekának, aki részt vett az adatgyújtésben. 


\section{Irodalom}

[1] Ranucci M, Baryshnikova E, Castelvecchio S, et al. Surgical and Clinical Outcome Research (SCORE) Group. Major bleeding, transfusions, and anemia: the deadly triad of cardiac surgery. Ann Thorac Surg. 2013; 96: 478-485.

[2] Fröjd V, Jeppsson A. Reexploration for bleeding and its association with mortality after cardiac surgery. Ann Thorac Surg. 2016; 102: 109-117.

[3] Petrou A, Tzimas P, Siminelakis S. Massive bleeding in cardiac surgery. Definitions, predictors and challenges. Hippokratia 2016; 20: 179-186.

[4] Biancari F, Kinnunen EM, Kiviniemi T, et al. Meta-analysis of the sources of bleeding after adult cardiac surgery. J Cardiothorac Vasc Anesth. 2018; 32: 1618-1624.

[5] Görlinger K, Shore-Lesserson L, Dirkmann D, et al. Management of hemorrhage in cardiothoracic surgery. J Cardiothorac Vasc Anesth. 2013; 27(4 Suppl): S20-S34.

[6] Görlinger K, Dirkmann D, Hanke AA, et al. First-line therapy with coagulation factor concentrates combined with point-ofcare coagulation testing is associated with decreased allogeneic blood transfusion in cardiovascular surgery: a retrospective, single-center cohort study. Anesthesiology 201 1; 115: 1179-1191.

[7] Csomós Á, Gál J. Cost-effectiveness of goal-directed coagulation management in clinical practice. [A célorientált alvadásgátló kezelés költséghatékonysága a mindennapi transzfúziós gyakorlatban.] Anaesthesiol Intens Ther. 2013; 43: 152-156. [Hungarian]

[8] Spalding GJ, Hartrumpf M, Sierig T, et al. Cost reduction of perioperative coagulation management in cardiac surgery: value of 'bedside' thrombelastography (ROTEM). Eur J Cardiothorac Surg. 2007; 31: 1052-1057.

[9] Babik B, Blaskó Gy, Fazakas J, et al. Treatment of life-threatening perioperative haemorrhage. Guideline. $[\mathrm{Az}$ életveszélyes perioperatív vérzések ellátása. Szakmai irányelv.] Anaesthesiol Intens Ther. 2013; 43: 113-143. [Hungarian]

[10] Kozek-Langenecker SA, Ahmed AB, Afshari A, et al. Management of severe perioperative bleeding: guidelines from the European Society of Anaesthesiology. First update 2016. Eur J Anaesthesiol. 2017; 34: 332-395.

[11] Moret E, Jacob MW, Ranucci M, et al. Albumin-beyond fluid replacement in cardiopulmonary bypass surgery: why, how, and when? Semin Cardiothorac Vasc Anesth. 2014; 18: 252-259.

[12] Ikezoe T. Thrombomodulin/activated protein C system in septic disseminated intravascular coagulation. J Intensive Care 2015; 3: 1

[13] Li C, Zhao Q, Yang K, et al. Thromboelastography or rotational thromboelastometry for bleeding management in adults undergoing cardiac surgery: a systematic review with meta-analysis and trial sequential analysis. J Thorac Dis. 2019; 11: 1170-1181.

[14] Corredor C, Wasowicz M, Karkouti K, et al. The role of pointof-care platelet function testing in predicting postoperative bleeding following cardiac surgery: a systematic review and me ta-analysis. Anaesthesia 2015; 70: 715-731.

[15] Loor G, Vivacqua A, Sabik JF 3rd, et al. Process improvement in cardiac surgery: development and implementation of a reoperation for bleeding checklist. J Thorac Cardiovasc Surg. 2013; 146: 1028-1032.

[16] Karthik S, Grayson AD, McCarron EE, et al. Reexploration for bleeding after coronary artery bypass surgery: risk factors, outcomes, and the effect of time delay. Ann Thorac Surg. 2004; 78 : $527-534$.

[17] Nuttall GA, Oliver WC, Santrach PJ, et al. Efficacy of a simple intraoperative transfusion algorithm for nonerythrocyte component utilization after cardiopulmonary bypass. Anesthesiology 2001; 94: 773-781. Discussion: 5A-6A.

[18] Shore-Lesserson L, Manspeizer HE, DePerio M, et al. Thromboelastography-guided transfusion algorithm reduces transfusions in complex cardiac surgery. Anesth Analg. 1999; 88: 312319.

[19] Afshari A, Wikkelsø A, Brok J, et al. Thrombelastography (TEG) or thromboelastometry (ROTEM) to monitor haemotherapy versus usual care in patients with massive transfusion. Cochrane Database Syst Rev. 2011; 3: CD007871.

[20] Bolliger D, Tanaka KA. Roles of thrombelastography and thromboelastometry for patient blood management in cardiac surgery. Transfus Med Rev. 2013; 27: 213-220.

[21] Karkouti K, McCluskey SA, Callum J, et al. Evaluation of a novel transfusion algorithm employing point-of-care coagulation assays in cardiac surgery: a retrospective cohort study with interrupted time-series analysis. Anesthesiology 2015; 122: 560-570.

[22] Weber CF, Görlinger K, Meininger D, et al. Point-of-care testing: a prospective, randomized clinical trial of efficacy in coagulopathic cardiac surgery patients. Anesthesiology 2012; 117: 531-547.

[23] Allen GA, Wolberg AS, Oliver JA, et al. Impact of procoagulant concentration on rate, peak and total thrombin generation in a model system. J Thromb Haemost. 2004; 2: 402-413.

[24] Ak K, Isbir CS, Tetik S, et al. Thromboelastography-based transfusion algorithm reduces blood product use after elective CABG: a prospective randomized study. J Card Surg. 2009; 24: 404410.

[25] Stanworth SJ, Grant-Casey J, Lowe D, et al. The use of freshfrozen plasma in England: high levels of inappropriate use in adults and children. Transfusion 2011; 51: 62c70.

[26] Shander A, Hofmann A, Ozawa S, et al. Activity-based costs of blood transfusions in surgical patients at four hospitals. Transfusion 2010; 50: 753-765.

(Gombocz Károly dr., Zalaegerszeg, Zrínyi u. 1., 8900 e-mail: gomboczk@gmail.com)

A cikk a Creative Commons Attribution 4.0 International License (https://creativecommons.org/licenses/by/4.0/) feltételei szerint publikált Open Access közlemény, melynek szellemében a cikk bármilyen médiumban szabadon felhasználható, megosztható és újraközölhetö, feltéve, hogy az eredeti szerző és a közlés helye, illetve a CC License linkje és az esetlegesen végrehajtott módosítások feltüntetésre kerülnek. (SID_1) 